
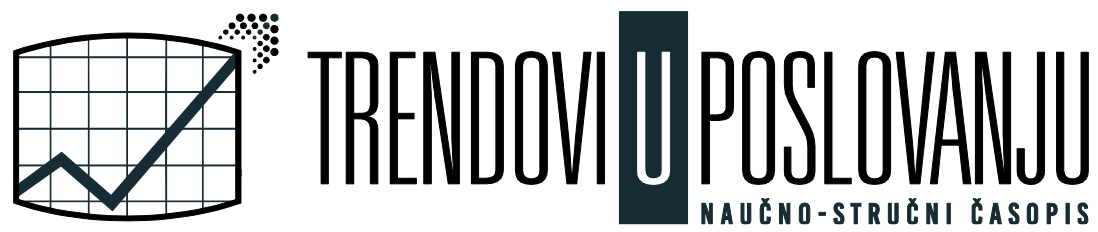

\author{
POVEZANOST BROJA MANIFESTACIJA SA \\ PROMOTIVNIM AKTIVNOSTIMA LOKALNIH \\ TURISTIČKIH ORGANIZACIJA I HOTELA NA \\ DRUŠTVENOJ MREŽI FACEBOOK
}

\title{
CONNECTION BETWEEN THE NUMBER OF MANIFESTATIONS AND PROMOTIONAL ACTIVITIES OF LOCAL TOURISM ORGANIZATIONS AND HOTELS ON THE SOCIAL NETWORK FACEBOOK
}

Dušan Garabinović | Visoka poslovna škola strukovnih studija „Prof. dr Radomir Bojković" Kruševac, | dusan.garabinovic.032@gmail.com

Slavica Anđelić | Visoka poslovna škola strukovnih studija „Prof. dr Radomir Bojković” Kruševac | slavica.andjelic@indmanager.edu.rs

\author{
UDC: $338.487: 659.1$ \\ 338.48-611:658.821: \\ Sažetak \\ 338.486.5:004.738.12FACEBOOK
}

Događaji, kao i drugi oblici turističke ponude, imaju potrebu za adekvatno osmišljenom i realizovanom promocijom u skladu sa svojim ali i karakteristikama i preferencijama ciljnog tržišta, gde savremena tehnološka rešenja sve više nalaze svoju primenu. Među pomenutim tehnologijama posebno treba istaći Internet, a u okviru njega društvene mreže. Manifestacije bi, međutim, trebalo da promovišu i organizacije koje imaju direktan ili posredan interes u njihovom održavanju. Kao jedan od najznačajnijih elemenata turističke ponude manifestacije bi trebalo da predstavljaju jedan od prioriteta u promociji od strane lokalnih turističkih organizacija, ali i hotela, obzirom da mogu u velikoj meri uticati na njihovu posećenost i broj noćenja. U skladu sa tim, cilj ovog rada je utvrdivanje postojanja povezanosti između broja događaja/manifestacija po mesecu i broja objava lokalnih turističkih organizacija i hotela na teritoriji Moravičkog upravnog okruga (Čačak, Lučani, Gornji Milanovac, Ivanjica) tokom 2018. godine na Facebook-u kao od strane analiziranih lokalnih turističkih organizacija i hotela najčešće korišćenoj društvenoj mreži.

\begin{abstract}
Events, as well as other types of tourist offer, need the appropriately designed and accomplished promotion according to their characteristics, but also the characteristics and preferences of the targeted market, where modern technological solutions find their implementation. Among the technologies mentioned, the Internet, and within it social networks, should be particularly emphasized. Manifestations should also be promoted by organizations with the immediate or indirect interest in holding these events. One of the most important elements of the manifestations tourist offer should also be one of the priorities in local tourist organizations offer, as well as hotels, considering the fact that they can largely influence the number of visitors and accommodation. According to this, the aim of this paper is to establish the connection between the number of events/manifestations per month and the number of posts by local tourist organizations and hotels in Moravica district territory (Cacak, Lucani, Gornji Milanovac, Ivanjica) in 2018, on Facebook as most used social network by the analyzed local tourism organizations and hotels.
\end{abstract}

KIjučne reči: turizam, marketing društvenih mreža, manifestacije, hoteli, lokalne turističke organizacije Keywords: tourism, social network marketing, manifestations, hotels, local tourist organizations 


\section{Uvod}

Internet i njegovo sve veće prisustvo u svakodnevnom životu predstavlja suštinu savremenih poslovnih aktivnosti marketara usmerenih ka identifikovanom ciljnom tržištu. Internet je, kao i marketing zasnovan na njemu, bio sam po sebi promena, ali promena koja i dalje determiniše nove promene. Potreba čoveka kao društvenog bića je da se socijalizuje, a u današnjim vremenima ova potreba se sve više zadovoljava upotrebom savremenih tehnologija, pre svega Interneta i društvenih mreža u okviru njih. Iz tog razloga je analiza uloge društvenih mreža značajna kako bi se unapredile marketing aktivnosti i u okviru njih promotivne aktivnosti pristupa kupcima (potrošačima, korisnicima), u svim delovima privrede uključujući i turizam, što je primetno i u Srbiji i Moravičkom upravnom okrugu kao njenom sastavnom delu.

Po osnovu prethodno rečenog, a u skladu sa rezultatima istraživanja [1] koje pokazuje da mladi (93,8\%), odnosno prema [2] da celina stanovnika Moravičkog upravnog okruga $(74,36 \%)$ kao glavni medij za informisanje/promovisanje o proizvodima/uslugama navodi Internet, postavlja se pitanje: Kakvo je prisustvo i korišćenje potencijala koje pruža Internet promocija u oblasti turizma Moravičkog upravnog okruga, posebno sa aspekta manifestacija kao jednog od najznačajnijih delova ukupne turističke ponude?

U skladu sa prethodnim pitanjem, predmet ovog rada je utvrđivanje povezanosti broja manifestacija sa aktivnostima lokalnih turističkih organizacija i hotela na društvenoj mreži Facebook.

Iz predmeta proističe i cilj rada, a to je utvrđivanje postojanja povezanosti između broja manifestacija po mesecu i broja objava lokalnih turističkih organizacija i hotela na teritoriji Moravičkog upravnog okruga (Cačak, Lučani, Gornji Milanovac, Ivanjica) tokom 2018. godine na Facebook-u kao najčešće korišćenoj društvenoj mreži.

\section{Manifestacije kao oblik turističkog proizvoda}

Događaji kao oblik turističke ponude mogu se posmatrati dvojako:

- kao element komunikacionog miksa (događaji i iskustva - ,aktivnosti i programi koje sponzoriše kompanija i koji su dizajnirani s ciljem kreiranja dnevne ili specijalne interakcije u vezi sa proizvodom“ [3]), ali i

- kao jedan od glavnih elemenata tržišne ponude [3].

Iz toga sledi da je događaj oblik tržišne ponude, ali ujedno čini jedan od promotivnih instrumenata, odnosno to je: (a) promotivni proizvod (ponuda), (b) promocija koja sama ima svoju vrednost (kao proizvod/ponuda).

Svi događaji imaju određenu zajedničku komponentu na osnovu koje se mogu posmatrati kao turistički. Događaji, na osnovu toga, obuhvataju turističke događaje, ali su ujedno i svi događaji turističke prirode. Iz toga proizilazi zaključak da razlika između termina „,događaj“ i ,turistički događaj" u okviru marketing koncepta kao pristupa tržištu nema.

Kao jedan od savremenih trendova u motivima (očekivanjima) turista prema [4] navodi se rast grupnih poseta značajnim proslavama i događajima, dok se kao turistički proizvodi od posebnog značaja za razvoj turizma pominju manifestacije/događaji (kulturni, sportski i dr) [4].

Prema istraživanju [5] zaključuje se da je neophodno ,sprovesti edukaciju organizatora manifestacija“ između ostalog i u vezi sa „marketinškim aktivnostima (promocija, brendiranje, distribucija i sl.)“ [5], koje su značajne i „u cilju boljeg tržišnog pozicioniranja i očuvanja lokalnog identiteta manifestacija“" [5].

Iz prethodnog se može zaključiti da su turistički događaji istovremeno važan deo ukupne turističke ponude, ali i snažan instrument promovisanja ostalih turističkih i privrednih potencijala. 


\section{Online marketing lokalnih turističkih organizacija}

Lokalni način posmatranja turističke ponude često zna dati mnogo bolje rezultate od sagledavanja ponude na nacionalnom nivou. Razlog za to se verovatno nalazi u činjenici da je svako geografsko područje, bez obzira koliko po veličini ono bilo, po određenim karakteristikama specifično i u većoj ili manjoj meri različito u odnosu na ostala. Kultura, način shvatanja posebnosti lokalnog područja predstavlja osnov kreiranja adekvatne turističke ponude, ponude koju najbolje može predstavljati organizacija koja tu posebnost na pravi način razume. Prednost lokalne turističke organizacije je što ona može lakše shvatiti podneblje i osetiti njegov ,način funkcionisanja“. Dakle, samo onaj ko razume vrednost turističkog proizvoda koji predstavlja za isti može zainteresovati i druge.

Nacionalne turističke organizacije zbog velike teritorije na kojoj funkcionišu, a u skladu sa ograničenim resursima, moraju napraviti izbor iz bogate turističke ponude često birajući turističke proizvode koji su trenutno aktuelni. Mnogi proizvodi na taj način ostaju neprepoznati kao nacionalno važni, pa njihovu vrednost moraju prezentovati turističke organizacije na nižim nivoima - pokrajinske, regionalne i lokalne.

U skladu sa navedenim, lokalne turističke organizacije su pronašle svoje mesto i ulogu u sveukupnom razvitku turističke privrede. One i dalje moraju konstantno pratiti privredna ali i društvena kretanja kako bi na pravi način kreirale, predstavile i realizovale turistički proizvod. Marketing, dakle, ima značajnu ulogu, a u savremenom poslovanju posebno se ističe Internet (online) marketing. U prilog tome su rezultati koji pokazuju da sajtovi lokalnih turističkih organizacija i sajtovi koji promovišu lokalnu turističku destinaciju zauzimaju najbolju poziciju po učestalosti korišćenja (40\%) [6] u sklopu šire posmatranih Internet sajtova (16\%) [6] od strane domaćih turista (Srbija).

\section{Online marketing hotela}

Doprinos razvoja Interneta poslovanju hotelskih preduzeća moguće je identifikovati u novim oblicima promocije koji se sve više zasnivaju na specijalizovanim Web sajtovima i društvenim mrežama koje istovremeno omogućavaju i aktivnosti rezervacije.

Kada je reč o prisutnosti hotela na Internetu, u [7] se navodi da iako nema velikog broja podataka o korišćenju društvenih mreža u hotelskom sektoru Srbije, ,može se primetiti da se u praksi najviše koriste 4 oblika društvenih mreža: Facebook, Instagram, Twitter i LinkedIn“ [7]. To se potvrđuje i u [8] gde je analizirano 331 kategorizovani hotel sa teritorije Srbije po osnovu prisustva na TripAdviser-u, Facebook-u, Twitter-u, YouTube-u i Instagram-u. Došlo se do zaključka da 270 hotela $(81,6 \%)$ ima prezentaciju na TripAdviser-u [8], dok je u okviru društvenih mreža Facebook na prvom mestu $(77,3 \%)$, zatim slede Twitter $(27,2 \%)$ i Instagram $(18,7 \%)$ [8], dok je na YouTubeu prezentovano $74,62 \%$ [8].

Da su sve organizacije međusobno u određenoj meri povezane pokazuje se i u [9] kroz predviđanje hotelske tražnje korišćenjem podataka o Web saobraćaju destinacijskih marketing organizacija.

Hoteli u Srbiji su, dakle, prisutni na društvenim mrežama (posebno na Facebook-u), ali ih ne treba posmatrati izolovano od drugih nosilaca turističke ponude, obzirom da određena zavisnost, kao što se moglo videti, zasigurno postoji. 


\section{Opis istraživanja}

Moravički upravni okrug predstavlja administrativno područje u Republici Srbiji koje uključuje četiri lokalne samouprave (Čačak, Lučani, Gornji Milanovac i Ivanjica), ukupne površine od oko $3.016 \mathrm{~km}^{2}$ i 212.603 stanovnika [10].

U skladu sa tematikom ovog rada, trebalo bi pomenuti da na teritoriji Moravičkog upravnog okruga postoje četiri lokalne turističke organizacije (Turistička organizacija Čačka, Turistička organizacija opštine Lučani „Dragačevo“, Turistička organizacija opštine Ivanjica i Turistička organizacija opštine Gornji Milanovac).

Istraživanje je sprovedeno 09. septembra 2019. godine prikupljanjem podataka koje je izvršeno u sledećim koracima:

- Utvrđen je broj turističkih manifestacija/događaja koji su tokom 2018. godine održane na teritoriji Moravičkog upravnog okruga (Čačak, Lučani, Gornji Milanovac, Ivanjica) po osnovu manifestacija/događaja koje su na zvaničnim Web sajtovima istaknute od strane lokalnih turističkih organizacija (Turistička organizacija Čačka, Turistička organizacija opštine Lučani „Dragačevo“, Turistička organizacija opštine Gornji Milanovac, Turistička organizacija opštine Ivanjica), kao i mesec(i) njihovog održavanja.

- Utvrđen je broj hotela sa teritorije Moravičkog upravnog okruga (Čačak, Lučani, Gornji Milanovac, Ivanjica) koji su kategorisani po osnovu podataka na Web sajtu Ministarstva trgovine, turizma i telekomunikacija Republike Srbije.

- Utvrđen je broj objava na Facebook-u (kao odabranoj društvenoj mreži) u 2018. godini po mesecima kod lokalnih turističkih organizacija i hotela.

- Utvrđivanje povezanosti broja održanih manifestacija po mesecima i ukupnog broja objava hotela, lokalnih turističkih organizacija i zbirno (hoteli i lokalne turističke organizacije) na nivou Moravičkog upravnog okruga kao celine, kao i u četiri lokalne samouprave koje čine Moravički upravni okrug uz njihovo međusobno poređenje.

Facebook je odabran po osnovu istraživanja [11] kao društvena mreža na osnovu toga što je to jedina društvena mreža za koju kod svih lokalnih turističkih organizacija u Moravičkog upravnom okrugu postoji link na Web sajtu, kao i iz razloga što je to jedina društvena mreža na kojoj sve četiri lokalne turističke organizacije imaju otvorene naloge i iste su koristile (bilo je objava) u 2018. godini.

\section{Rezultati istraživanja i diskusija}

$\mathrm{Na}$ osnovu posete zvaničnim veb-sajtovima lokalnih turističkih organizacija u Moravičkom upravnom okrugu, utvrđeno je da je ukupan broj manifestacija koje su održane tokom 2018. godine 64, odnosno po lokalnim samoupravama: Čačak (42) [12], Gornji Milanovac (10) [13], Lučani (6) [14] i Ivanjica (6) [15]. Pojedine manifestacije se održavaju u dva ili više meseci, pa su u skladu sa tim, takve manifestacije uračunate u ukupan broj manifestacija za svaki mesec njihovog trajanja. Pregled zastupljenosti manifestacija po lokalnim samoupravama, Moravičkom upravnom okrugu kao celini i mesecima održavanja dat je u sledećoj tabeli (tabela 1). 
Tabela 1. Pregled manifestacijama po lokalnim samoupravama, Moravičkom upravnom okrugu kao celini i mesecu održavanja

\begin{tabular}{|c|c|c|c|c|c|c|c|c|c|}
\hline & Čač & & Luč & & $\begin{array}{l}\text { Gor } \\
\text { Mila }\end{array}$ & $\begin{array}{l}\text { lji } \\
\text { novac }\end{array}$ & Iva & njica & UKUPNO \\
\hline & Br. & $\%$ & $\mathrm{Br}$. & $\%$ & Br. & $\%$ & Br. & $\%$ & Br. \\
\hline Januar & 4 & $100,00 \%$ & 0 & $0,00 \%$ & 0 & $0,00 \%$ & 0 & $0,00 \%$ & 4 \\
\hline Februar & 2 & $66,67 \%$ & 0 & $0,00 \%$ & 0 & $0,00 \%$ & 1 & $33,33 \%$ & 3 \\
\hline Mart & 4 & $100,00 \%$ & 0 & $0,00 \%$ & 0 & $0,00 \%$ & 0 & $0,00 \%$ & 4 \\
\hline April & 4 & $50,00 \%$ & 1 & $12,50 \%$ & 3 & $37,50 \%$ & 0 & $0,00 \%$ & 8 \\
\hline Maj & 8 & $80,00 \%$ & 0 & $0,00 \%$ & 1 & $10,00 \%$ & 1 & $10,00 \%$ & 10 \\
\hline Jun & 6 & $60,00 \%$ & 1 & $10,00 \%$ & 2 & $20,00 \%$ & 1 & $10,00 \%$ & 10 \\
\hline Jul & 4 & $57,14 \%$ & 1 & $14,29 \%$ & 2 & $28,57 \%$ & 0 & $0,00 \%$ & 7 \\
\hline Avgust & 5 & $45,45 \%$ & 1 & $9,09 \%$ & 2 & $18,18 \%$ & 3 & $27,27 \%$ & 11 \\
\hline Septembar & 8 & $80,00 \%$ & 1 & $10,00 \%$ & 1 & $10,00 \%$ & 0 & $0,00 \%$ & 10 \\
\hline Oktobar & 0 & $0,00 \%$ & 0 & $0,00 \%$ & 1 & $100,00 \%$ & 0 & $0,00 \%$ & 1 \\
\hline Novembar & 1 & $50,00 \%$ & 1 & $50,00 \%$ & 0 & $0,00 \%$ & 0 & $0,00 \%$ & 2 \\
\hline Decembar & 4 & $100,00 \%$ & 0 & $0,00 \%$ & 0 & $0,00 \%$ & 0 & $0,00 \%$ & 4 \\
\hline
\end{tabular}

Izvor: Istraživanje autora

U cilju jasnijeg prikaza zastupljenosti manifestacija održanih na teritoriji Moravičkog upravnog okruga u 2018. godini, dat je i grafički prikaz (slika 1).

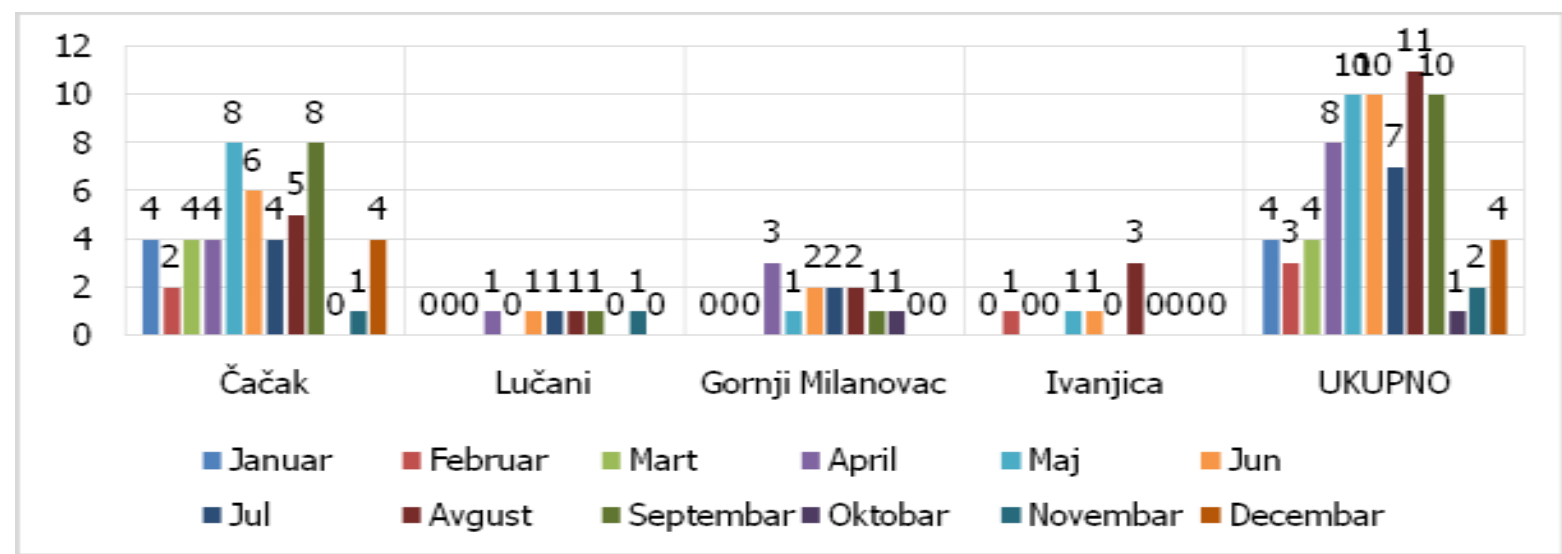

Slika 1. Pregled manifestacija po lokalnim samoupravama, Moravičkom upravnom okrugu kao celini i mesecu održavanja

Izvor: Istraživanje autora

Po osnovu tabele 1 i slike 1 jasno se može zaključiti da najveći doprinos broju manifestacija ima grad Čačak, koji ima najveće učešće u broju manifestacija u svim mesecima sa izuzetkom oktobra meseca (Gornji Milanovac, 100,00\%). Najčešća situacija je da se na mesečnom nivou organizuju manifestacije u jednoj ili tri lokalne samouprave (po 4 meseca).

U sledećoj tabeli (tabela 2) data je deskriptivna statistika za manifestacije u Moravičkom upravnom okrugu. 
Tabela 2. Deskriptivna statistika broja manifestacija po mesecima

\begin{tabular}{|l|r|r|r|r|r|}
\hline & \multicolumn{1}{|c|}{ Čačak } & \multicolumn{1}{c|}{ Lučani } & \multicolumn{1}{|c|}{ Gornji } & \multicolumn{1}{l|}{ Milanovac } & UKUPNo \\
\hline Prosek & 4,17 & 0,50 & 1 & 0,50 & 6,17 \\
\hline $\begin{array}{l}\text { Standardna } \\
\text { greška }\end{array}$ & 0,71 & 0,15 & 0,30 & 0,26 & 1,03 \\
\hline Medijana & 4 & 0,50 & 1 & 0 & 5,50 \\
\hline Mod & 4 & $0 \mathrm{i} 1$ & 0 & 0 & 4 i 10 \\
\hline $\begin{array}{l}\text { Standardna } \\
\text { devijacija }\end{array}$ & 2,44 & 0,52 & 1,04 & 0,90 & 3,56 \\
\hline Varijansa & 5,97 & 0,27 & 1,09 & 0,82 & 12,70 \\
\hline Rang & 8 & 1 & 3 & 3 & 10 \\
\hline Minimum & 0 & 0 & 0 & 0 & 1 \\
\hline Maksimum & 8 & 1 & 3 & 3 & 11 \\
\hline
\end{tabular}

\section{Izvor: Istraživanje autora}

Kao što se iz prethodne tabele (tabela 2) može videti najveći prosek manifestacija po mesecu, standardnu grešku, medijanu, mod, standardnu devijaciju i maksimum ima grad Čačak. Najmanji prosek (zajedno sa Ivanjicom), standardnu grešku, mod (0 zajedno sa Gornjim Milanovcem i Ivanjicom; napomena: postoji i mod 1), standardnu devijaciju, varijansu, rang i maksimum ima opština Lučani. Kada je reč o Moravičkom upravnom okrugu kao celini prosek manifestacija po mesecu je 6,17, dok je najčešći broj 4 (januar, mart i decembar) i 10 (maj, jun, septembar), ne postoji mesec bez bar jedne manifestacije (minimum $1 \mathrm{u}$ oktobru), dok je maksimalan broj zabeležen $\mathrm{u}$ avgustu (11). Jedina značajnija korelisanost između lokalnih samouprava utvrđena je između broja manifestacija po mesecu između Lučana i Gornjeg Milanovca $(0,67)$.

Analizom spiska kategorisanih smeštajnih objekata tipa hotel/garni hotel na Web sajtu Ministarstva trgovine, turizma i telekomunikacija Republike Srbije [16] utvrđeno je da na teritoriji Moravičkog upravnog okruga postoji ukupno 12 objekata, i to najviše u Čačku (7; 58,33\%), potom u Ivanjici i Lučanima (po 2; po 16,67\%) i Gornjem Milanovcu (1; 8,33\%).

Sve četiri lokalne turističke organizacije sa teritorije Moravičkog upravnog okruga imaju otvorene naloge (stranice) na društvenoj mreži Facebook i iste su koristile tokom 2018. godine [11]. To je i razlog za odabir ove društvene mreže za dalju analizu. U sledećoj tabeli (tabela 3) je dat pregled korišćenja Facebook-a tokom 2018. godine od strane lokalnih turističkih organizacija i hotela u Moravičkom upravnom okrugu.

Tabela 3. Facebook - otvoreni nalozi i korišćenje naloga u 2018. godini (lokalne turističke organizacije i hoteli u Moravičkom upravnom okrugu)

\begin{tabular}{|c|c|c|c|c|}
\hline & \multicolumn{2}{|c|}{ Lokalne turističke organizacije } & \multicolumn{2}{|c|}{ Hoteli } \\
\hline & Broj & $\%$ & Broj & $\%$ \\
\hline $\begin{array}{l}\text { Postoji otvoren } \\
\text { nalog }\end{array}$ & 4 & $100,00 \%$ & 10 & $83,33 \%$ \\
\hline $\begin{array}{l}\text { Korišćen nalog u } \\
\text { 2018. godini }\end{array}$ & 4 & $100,00 \%$ & 8 & $66,67 \%$ \\
\hline
\end{tabular}

Izvor: Istraživanje autora i [11]

28 VISOKA ŠKOLA ZA POSLOVNU EKONOMIJU I PREDUZETNIŠTVO, BEOGRAD, SRBIJA 
Kao što se u prethodnoj tabeli (tabela 3) može videti, većina hotela ima otvoren nalog na Facebook$\mathrm{u}$ i isti je koristila tokom 2018. godine (bilo je objava).

Analizom Facebook stranica četiri lokalne turističke organizacije (Čačak, Lučani, Gornji Milanovac i Ivanjica) došlo se do podataka o raspodeli objava po mesecima tokom 2018. godine. Rezultati su dati u sledećoj tabeli (tabela 4).

Tabela 4. Broj objava na Facebook-u lokalnih turističkih organizacija u 2018. godini po mesecima

\begin{tabular}{|c|c|c|c|c|c|c|c|c|c|c|}
\hline & \multicolumn{2}{|c|}{ Čačak } & \multicolumn{2}{|c|}{ Lučani } & \multicolumn{2}{|c|}{$\begin{array}{c}\text { Gornji } \\
\text { Milanovac }\end{array}$} & \multicolumn{2}{|c|}{ Ivanjica } & \multicolumn{2}{|c|}{ UKUPNO } \\
\hline & Br. & $\%$ & Br. & $\%$ & Br. & $\%$ & Br. & $\%$ & Br. & $\%$ \\
\hline Januar & 8 & $38,10 \%$ & 5 & $23,81 \%$ & 6 & $28,57 \%$ & 2 & $9,52 \%$ & 21 & $4,54 \%$ \\
\hline Februar & 16 & $39,02 \%$ & 11 & $26,83 \%$ & 8 & $19,51 \%$ & 6 & $14,63 \%$ & 41 & $8,86 \%$ \\
\hline Mart & 18 & $58,06 \%$ & 3 & $9,68 \%$ & 8 & $25,81 \%$ & 2 & $6,45 \%$ & 31 & $6,70 \%$ \\
\hline April & 9 & $25,00 \%$ & 7 & $19,44 \%$ & 20 & $55,56 \%$ & 0 & $0,00 \%$ & 36 & $7,78 \%$ \\
\hline Maj & 12 & $35,29 \%$ & 5 & $14,71 \%$ & 16 & $47,06 \%$ & 1 & $2,94 \%$ & 34 & $7,34 \%$ \\
\hline Jun & 8 & $22,22 \%$ & 13 & $36,11 \%$ & 9 & $25,00 \%$ & 6 & $16,67 \%$ & 36 & $7,78 \%$ \\
\hline Jul & 18 & $43,90 \%$ & 14 & $34,15 \%$ & 3 & $7,32 \%$ & 6 & $14,63 \%$ & 41 & $8,86 \%$ \\
\hline Avgust & 17 & $23,61 \%$ & 8 & $11,11 \%$ & 1 & $1,39 \%$ & 46 & $63,89 \%$ & 72 & $15,55 \%$ \\
\hline Septembar & 12 & $30,77 \%$ & 2 & $5,13 \%$ & 7 & $17,95 \%$ & 18 & $46,15 \%$ & 39 & $8,42 \%$ \\
\hline Oktobar & 21 & $50,00 \%$ & 5 & $11,90 \%$ & 9 & $21,43 \%$ & 7 & $16,67 \%$ & 42 & $9,07 \%$ \\
\hline Novembar & 10 & $35,71 \%$ & 5 & $17,86 \%$ & 8 & $28,57 \%$ & 5 & $17,86 \%$ & 28 & $6,05 \%$ \\
\hline Decembar & 8 & $19,05 \%$ & 3 & $7,14 \%$ & 9 & $21,43 \%$ & 22 & $52,38 \%$ & 42 & $9,07 \%$ \\
\hline UKUPNO & 157 & $33,91 \%$ & 81 & $17,49 \%$ & 104 & $22,46 \%$ & 121 & $26,13 \%$ & 463 & $100,00 \%$ \\
\hline
\end{tabular}

Napomena: \%* - procenat od ukupnog broja objava na Facebook-u u toku godine

\section{Izvor: Istraživanje autora}

Iz prethodne tabele (tabela 4) se jasno zaključuje da Turistička organizacija Čačka daje najveći doprinos ukupnom broju objava na Facebook-u (33,91\%), što se posebno ističe tokom šest meseci (mart, oktobar, jul, februar, januar i novembar). Potom sledi Turistička organizacija opštine Ivanjica $(26,13 \%)$ koja, pored toga što daje najveći doprinos u tri meseca (avgust, decembar i septembar), ima i najveće procentualno učešće u broju objava u jednom mesecu (avgust 63,89\%). Turistička organizacija opštine Gornji Milanovac $(22,46 \%)$ najviše doprinosi broju objava u toku dva meseca (april, maj), dok je najslabija zastupljenost objava Turističke organizacije opštine Lučani „Dragačevo“ (17,49\%) - jedan mesec (jun).

U sledećoj tabeli (tabela 5) data je deskriptivna statistika za broj objava na Facebook-u lokalnih turističkih organizacija iz Moravičkog upravnog okruga tokom 12 meseci 2018. godine. 
Tabela 5. Deskriptivna statistika - broj objava na Facebook-u lokalnih turističkih organizacija iz Moravičkog upravnog okruga u 2018. godini

\begin{tabular}{|l|r|r|r|r|r|}
\hline & \multicolumn{1}{|c|}{ Čačak } & \multicolumn{1}{c|}{ Lučani } & $\begin{array}{c}\text { Gornji } \\
\text { Milanovac }\end{array}$ & Ivanjica & UKUPNO \\
\hline Prosek & 13,08 & 6,75 & 8,67 & 10,08 & 38,58 \\
\hline $\begin{array}{l}\text { Standardna } \\
\text { greška }\end{array}$ & 1,35 & 1,15 & 1,47 & 3,79 & 3,55 \\
\hline Medijana & 12 & 5 & 8 & 6 & 37,50 \\
\hline Mod & 8 & 5 & $8 \mathrm{i} 9$ & 6 & $36 ; 41$ i 42 \\
\hline $\begin{array}{l}\text { Standardna } \\
\text { devijacija }\end{array}$ & 4,68 & 4 & 5,09 & 13,12 & 12,30 \\
\hline Varijansa & 21,90 & 15,84 & 25,88 & 172,27 & 151,36 \\
\hline Rang & 13 & 12 & 19 & 46 & 51 \\
\hline Minimum & 8 & 2 & 1 & 0 & 21 \\
\hline Maksimum & 21 & 14 & 20 & 46 & 72 \\
\hline Zbir & 157 & 81 & 104 & 121 & 463 \\
\hline
\end{tabular}

Izvor: Istraživanje autora

Dakle, Turistička organizacija Čačka ima najveći prosek objava po mesecu, medijanu i minimum, Turistička organizacija opštine Ivanjica ima najveću standardnu grešku, standardnu devijaciju i varijansu, a Turistička organizacija Gornjeg Milanovca ima najveći mod (9) i rang. Turistička organizacija opštine Lučani „Dragačevo“ ima najmanje vrednosti svih prethodno navedenih pokazatelja, sa izuzetkom najmanje minimalne vrednosti (Turistička organizacija opštine Ivanjica). Prosečan broj objava lokalnih turističkih organizacija u Moravičkom upravnom okrugu kao celini je 38,58 , standardna greška 3,55, medijana 37,50 , broj objava koji se najčešće ponavlja (mod) je 36, 41 i 42, standardna devijacija 12,30, varijansa 151,36, rang 51, minimum 21 (januar), maksimum 72 (avgust).

Analizom Facebook stranica hotela sa teritorije Moravičkog upravnog okruga (Čačak, Lučani, Gornji Milanovac i Ivanjica) došlo se do podataka o raspodeli objava po mesecima tokom 2018. godine. Rezultati su dati u sledećoj tabeli (tabela 6).

Tabela 6. Broj objava na Facebook-u hotela u 2018. godini po mesecima

\begin{tabular}{|l|r|r|r|r|r|r|r|r|r|r|}
\hline \multirow{2}{*}{} & \multicolumn{2}{|c|}{ Čačak } & \multicolumn{2}{c|}{ Lučani } & \multicolumn{2}{c|}{$\begin{array}{c}\text { Gornji } \\
\text { Milanovac }\end{array}$} & \multicolumn{2}{c|}{ Ivanjica } & \multicolumn{2}{c|}{ UKUPNO } \\
\cline { 2 - 12 } & Br. & \multicolumn{1}{c|}{$\%$} & Br. & \multicolumn{1}{c|}{$\%$} & Br. & \multicolumn{1}{c|}{$\%$} & Br. & $\%$ & Br. & $\%$ \%* \\
\hline Januar & 13 & $28,26 \%$ & 4 & $8,70 \%$ & 4 & $8,70 \%$ & 25 & $54,35 \%$ & 46 & $10,98 \%$ \\
\hline Februar & 5 & $12,20 \%$ & 5 & $12,20 \%$ & 8 & $19,51 \%$ & 23 & $56,10 \%$ & 41 & $9,79 \%$ \\
\hline Mart & 6 & $14,63 \%$ & 3 & $7,32 \%$ & 10 & $24,39 \%$ & 22 & $53,66 \%$ & 41 & $9,79 \%$ \\
\hline April & 8 & $19,51 \%$ & 6 & $14,63 \%$ & 8 & $19,51 \%$ & 19 & $46,34 \%$ & 41 & $9,79 \%$ \\
\hline Maj & 5 & $18,52 \%$ & 4 & $14,81 \%$ & 2 & $7,41 \%$ & 16 & $59,26 \%$ & 27 & $6,44 \%$ \\
\hline Jun & 0 & $0,00 \%$ & 3 & $16,67 \%$ & 0 & $0,00 \%$ & 15 & $83,33 \%$ & 18 & $4,30 \%$ \\
\hline Jul & 4 & $14,81 \%$ & 4 & $14,81 \%$ & 1 & $3,70 \%$ & 18 & $66,67 \%$ & 27 & $6,44 \%$ \\
\hline Avgust & 1 & $4,55 \%$ & 3 & $13,64 \%$ & 2 & $9,09 \%$ & 16 & $72,73 \%$ & 22 & $5,25 \%$ \\
\hline
\end{tabular}

30 VISOKA ŠKOLA ZA POSLOVNU EKONOMIJU I PREDUZETNIŠTVO, BEOGRAD, SRBIJA 


\begin{tabular}{|l|r|r|r|r|r|r|r|r|r|r|}
\hline Septembar & 1 & $4,55 \%$ & 0 & $0,00 \%$ & 6 & $27,27 \%$ & 15 & $68,18 \%$ & 22 & $5,25 \%$ \\
\hline Oktobar & 1 & $2,70 \%$ & 1 & $2,70 \%$ & 11 & $29,73 \%$ & 24 & $64,86 \%$ & 37 & $8,83 \%$ \\
\hline Novembar & 12 & $26,09 \%$ & 7 & $15,22 \%$ & 7 & $15,22 \%$ & 20 & $43,48 \%$ & 46 & $10,98 \%$ \\
\hline Decembar & 17 & $33,33 \%$ & 13 & $25,49 \%$ & 5 & $9,80 \%$ & 16 & $31,37 \%$ & 51 & $12,17 \%$ \\
\hline UKUPNO & 73 & $17,42 \%$ & 53 & $12,65 \%$ & 64 & $15,27 \%$ & 229 & $54,65 \%$ & 419 & $100,00 \%$ \\
\hline
\end{tabular}

Napomena: \%* - procenat od ukupnog broja objava na Facebook-u u toku godine

\section{Izvor: Istraživanje autora}

$\mathrm{Na}$ osnovu analize prethodne tabele (tabela 6) može se uočiti da su hoteli iz Ivanjice imali najveći udeo u objavama hotela u Moravičkom upravnom okrugu (54,65\%), i to u 11 od 12 analiziranih meseci (sa izuzetkom decembra - Čačak 33,33\%; drugi po ukupnom učešću 17,42\%). Nakon Ivanjice i Čačka slede Gornji Milanovac (15,27\%) i Lučani (12,65\%).

U sledećoj tabeli (tabela 7) data je deskriptivna statistika za broj objava na Facebook-u hotela iz Moravičkog upravnog okruga tokom 12 meseci 2018. godine.

Tabela 7. Deskriptivna statistika - broj objava na Facebook-u hotela iz Moravičkog upravnog okruga u 2018. godini

\begin{tabular}{|l|r|r|r|r|r|}
\hline & \multicolumn{1}{|c|}{ Čačak } & \multicolumn{1}{c|}{ Lučani } & $\begin{array}{c}\text { Gornji } \\
\text { Milanovac }\end{array}$ & Ivanjica & UKUPNO \\
\hline Prosek & 6,08 & 4,42 & 5,33 & 19,08 & 34,92 \\
\hline Standardna greška & 1,57 & 0,96 & 1,04 & 1,05 & 3,22 \\
\hline Medijana & 5 & 4 & 5,50 & 18,50 & 39 \\
\hline Mod & 1 & 3 i 4 & 2 i 8 & 16 & 41 \\
\hline $\begin{array}{l}\text { Standardna } \\
\text { devijacija }\end{array}$ & 5,45 & 3,32 & 3,60 & 3,65 & 11,14 \\
\hline Varijansa & 29,72 & 10,99 & 12,97 & 13,36 & 124,08 \\
\hline Rang & 17 & 13 & 11 & 10 & 33 \\
\hline Minimum & 0 & 0 & 0 & 15 & 18 \\
\hline Maksimum & 17 & 13 & 11 & 25 & 51 \\
\hline Zbir & 73 & 53 & 64 & 229 & 419 \\
\hline
\end{tabular}

Izvor: Istraživanje autora

Hoteli sa teritorije opštine Ivanjica imaju najveći prosek, medijanu, mod, minimum i maksimum i imaju najmanji rang, dok hoteli sa teritorije grada Čačka imaju najveću standardnu grešku, standardnu devijaciju, varijansu i rang i imaju najmanji mod. Hoteli sa teritorije opštine Lučani imaju najmanji prosek, standardnu grešku, medijanu, standardnu devijaciju i rang, dok hoteli sa teritorije Gornjeg Milanovca imaju najmanji maksimum. Hoteli sa teritorije Moravičkog upravnog okruga imaju prosek objava 34,92, standardnu grešku 3,22, medijanu 39, mod 41, standardnu devijaciju 11,14, varijansu 124,08, rang 33, minimum 18 (jun) i maksimum 51 (decembar).

U sledećoj tabeli (tabela 8) dati su podaci o ukupnom broju objava (lokalne turističke organizacije i hoteli) tokom 12 meseci 2018. godine po lokalnim samoupravama i u celini Moravičkog upravnog okruga. 
Tabela 8. Ukupan broj objava na Facebook-u (lokalne turističke organizacije i hoteli) u 2018. godini po mesecima

\begin{tabular}{|c|c|c|c|c|c|c|c|c|c|c|}
\hline & & ačak & & ıčani & & $\begin{array}{l}\text { ornji } \\
\text { anovac }\end{array}$ & & anjica & & JPNO \\
\hline & $\mathrm{Br}$. & $\%$ & $\mathrm{Br}$. & $\%$ & Br. & $\%$ & Br. & $\%$ & Br. & \%* \\
\hline Januar & 21 & $31,34 \%$ & 9 & $13,43 \%$ & 10 & $14,93 \%$ & 27 & $40,30 \%$ & 67 & $7,60 \%$ \\
\hline Februar & 21 & $25,61 \%$ & 16 & $19,51 \%$ & 16 & $19,51 \%$ & 29 & $35,37 \%$ & 82 & $9,30 \%$ \\
\hline Mart & 24 & $33,33 \%$ & 6 & $8,33 \%$ & 18 & $25,00 \%$ & 24 & $33,33 \%$ & 72 & $8,16 \%$ \\
\hline April & 17 & $22,08 \%$ & 13 & $16,88 \%$ & 28 & $36,36 \%$ & 19 & $24,68 \%$ & 77 & $8,73 \%$ \\
\hline Maj & 17 & $27,87 \%$ & 9 & $14,75 \%$ & 18 & $29,51 \%$ & 17 & $27,87 \%$ & 61 & $6,92 \%$ \\
\hline Jun & 8 & $14,81 \%$ & 16 & $29,63 \%$ & 9 & $16,67 \%$ & 21 & $38,89 \%$ & 54 & $6,12 \%$ \\
\hline Jul & 22 & $32,35 \%$ & 18 & $26,47 \%$ & 4 & $5,88 \%$ & 24 & $35,29 \%$ & 68 & $7,71 \%$ \\
\hline Avgust & 18 & $19,15 \%$ & 11 & $11,70 \%$ & 3 & $3,19 \%$ & 62 & $65,96 \%$ & 94 & $10,66 \%$ \\
\hline Septembar & 13 & $21,31 \%$ & 2 & $3,28 \%$ & 13 & $21,31 \%$ & 33 & $54,10 \%$ & 61 & $6,92 \%$ \\
\hline Oktobar & 22 & $27,85 \%$ & 6 & $7,59 \%$ & 20 & $25,32 \%$ & 31 & $39,24 \%$ & 79 & $8,96 \%$ \\
\hline Novembar & 22 & $29,73 \%$ & 12 & $16,22 \%$ & 15 & $20,27 \%$ & 25 & $33,78 \%$ & 74 & $8,39 \%$ \\
\hline Decembar & 25 & $26,88 \%$ & 16 & $17,20 \%$ & 14 & $15,05 \%$ & 38 & $40,86 \%$ & 93 & $10,54 \%$ \\
\hline UKUPNO & $\begin{array}{r}23 \\
0\end{array}$ & $26,08 \%$ & 134 & $15,19 \%$ & 168 & $19,05 \%$ & 350 & $39,68 \%$ & 882 & $\begin{array}{r}100,00 \\
\%\end{array}$ \\
\hline
\end{tabular}

Izvor: Istraživanje autora

Po osnovu prethodne tabele (tabela 8) može se zaključiti da najveće učešće u ukupnom broju objava ima Ivanjica (39,68\%), pri čemu ima najveći doprinos u 10 analiziranih meseci. Na drugoj poziciji nalazi se Čačak (26,08\%; 1 mesec - mart deli prvo mesto sa Ivanjicom), zatim Gornji Milanovac $(19,05 \% ; 2$ meseca) i na kraju sa najmanjim učešćem se nalaze Lučani $(15,19 \%)$.

U sledećoj tabeli (tabela 9) data je deskriptivna statistika za ukupan broj objava na Facebook-u (lokalne turističke organizacije i hoteli) u Moravičkom upravnom okrugu tokom 12 meseci 2018. godine.

Tabela 9. Deskriptivna statistika - Ukupan broj objava na Facebook-u (lokalne turističke organizacije i hoteli) u Moravičkom upravnom okrugu u 2018. godini

\begin{tabular}{|l|r|r|r|r|r|}
\hline & \multicolumn{1}{|c|}{ ČA } & \multicolumn{1}{c|}{ LU } & \multicolumn{1}{c|}{ GM } & \multicolumn{1}{c|}{ IC } & \multicolumn{1}{c|}{ UKUPNO } \\
\hline Prosek & 19,17 & 11,17 & 14 & 29,17 & 73,50 \\
\hline Standardna greška & 1,41 & 1,42 & 2,01 & 3,45 & 3,57 \\
\hline Medijana & 21 & 11,50 & 14,50 & 26 & 73 \\
\hline Mod & 22 & 16 & 18 & 24 & 61 \\
\hline $\begin{array}{l}\text { Standardna } \\
\text { devijacija }\end{array}$ & 4,88 & 4,93 & 6,95 & 11,94 & 12,37 \\
\hline Varijansa & 23,79 & 24,33 & 48,36 & 142,52 & 153 \\
\hline Rang & 17 & 16 & 25 & 45 & 40 \\
\hline
\end{tabular}

32 VISOKA ŠKOLA ZA POSLOVNU EKONOMIJU I PREDUZETNIŠTVO, BEOGRAD, SRBIJA 


\begin{tabular}{|l|r|r|r|r|r|}
\hline Minimum & 8 & 2 & 3 & 17 & 54 \\
\hline Maksimum & 25 & 18 & 28 & 62 & 94 \\
\hline Zbir & 230 & 134 & 168 & 350 & 882 \\
\hline
\end{tabular}

Izvor: Istraživanje autora

Iz prethodne tabele (tabela 9) se može videti da Ivanjica ima najviše vrednosti po svim navedenim pokazateljima, dok Lučani imaju najmanje vrednosti svih pokazatelja, sa izuzetkom standardne greške i standardne devijacije (Čačak). Prosečan ukupan broj objava u Moravičkom upravnom okrugu je 73,5, standardna greška 3,57, medijana 73, mod 61, standardna devijacija 12,37, varijansa 153, rang 40, minimum 54 (jun) i maksimum 94 (avgust).

U sledećoj tabeli (tabela 10) je prikazana korelisanost broja objava na Facebook-u i broja manifestacija po mesecima u 2018. godini, i to pojedinačno u svakoj od lokalnih samouprava i u celini Moravičkog upravnog okruga.

Tabela 10. Korelisanost broja objava na Facebook-u i broja manifestacija u 2018. godini

\begin{tabular}{|l|c|c|r|r|r|}
\hline & Čačak & Lučani & \multicolumn{1}{c|}{$\begin{array}{c}\text { Gornji } \\
\text { Milanovac }\end{array}$} & \multicolumn{1}{c|}{ Ivanjica } & \multicolumn{1}{c|}{$\begin{array}{c}\text { Moravički } \\
\text { upravni } \\
\text { okrug }\end{array}$} \\
\hline $\begin{array}{l}\text { Lokalne } \\
\text { turističke } \\
\text { organizacije }\end{array}$ & $-0,343196306$ & 0,371767914 & 0,239535069 & 0,692998455 & 0,412331543 \\
\hline Hoteli & $-0,253666196$ & $-0,183765649$ & $-0,362526183$ & $-0,343758325$ & $-0,803528707$ \\
\hline Ukupno & $-0,612842818$ & 0,176446168 & $-0,012515654$ & 0,656668957 & $-0,313512705$ \\
\hline
\end{tabular}

Izvor: Istraživanje autora

Značajnije vrednosti pozitivne korelacije $(>0,5)$ zabeležene su između broja objava lokalne turističke organizacije u Ivanjici i broja manifestacija u Ivanjici $(0,692998455)$, kao i između ukupnog broja objava (lokalna turistička organizacija i hoteli) u Ivanjici i broja manifestacija u Ivanjici $(0,656668957)$. Značajnije vrednosti negativne korelacije zabeležene su između broja objava hotela u Moravičkom upravnom okrugu i broja manifestacija u Moravičkom upravnom okrugu (-0,803528707), kao i između ukupnog broja objava (lokalne turističke organizacije i hoteli) u Čačku i broja manifestacija u Čačku $(-0,612842818)$.

\section{Zaključak}

Marketing zasnovan na društvenim mrežama kao oblik Internet marketinga ima sve značajniju ulogu u promovisanju turističkih potencijala u savremenom svetu. Manifestacije kao oblik turističkog proizvoda takođe svoju promociju u velikoj meri zasnivaju na online marketinškim aktivnostima, ali je potrebno istaći da one pružaju priliku i marketarima lokalnih turističkih organizacija, hotela i sl. za korišćenje kao promotivnog instrumenta.

Od svih lokalnih turističkih organizacija koje su analizirane Turistička organizacija Čačka ima najveću zastupljenost u broju objava na Facebook-u tokom 2018 godine (33,91\%), dok Turistička organizacija opštine Lučani „Dragačevo“ ima najmanje učešće (17,49\%). Kada je reč o hotelima, najviše objava na Facebook-u tokom 2018. godine imali su hoteli sa teritorije opštine Ivanjica $(54,65 \%)$, a najmanje hoteli iz opštine Lučani (12,65\%). U ukupnom broju objava (lokalne turističke organizacije i hoteli) tokom 2018. godine najveći udeo imala je opština Ivanjica (39,68\%), dok je najmanji udeo opštine Lučani $(15,19 \%)$. 
Korelisanost broja manifestacija i broja objava na Facebook-u, uočena je u značajnijom meri između broja objava lokalne turističke organizacije u Ivanjici i broja manifestacija u Ivanjici (0,692998455), kao i između ukupnog broja objava (lokalna turistička organizacija i hoteli) u Ivanjici i broja manifestacija u Ivanjici $(0,656668957)$ - pozitivna korelacija, kao i između broja objava hotela u Moravičkom upravnom okrugu i broja manifestacija u Moravičkom upravnom okrugu $(-0,803528707)$, kao i između ukupnog broja objava (lokalne turističke organizacije i hoteli) u Čačku i broja manifestacija u Čačku $(-0,612842818)$ - negativna korelacija. Iz navedenog se zaključuje da ne postoji opšta korelisanost broja manifestacija po mesecu održavanja i broja objava lokalnih turističkih organizacija i hotela na društvenoj mreži Facebook u Moravičkom upravnom okrugu (za 2018. godinu).

Doprinos ovog rada ogleda se u utvrđivanju stepena povezanosti broja manifestacija/događaja koje se održavaju sa brojem objava na društvenim mrežama (Facebook), kako bi se (u slučaju Moravičkog upravnog okruga) ukazalo na nedovoljnu iskorišćenost manifestacija u marketingu baziranom na društvenim mrežama od strane lokalnih turističkih organizacija i kategorisanih hotelskih smeštajnih kapaciteta, iako od njihovog održavanja (jedan od glavnih turističkih proizvoda) imaju direktan interes.

Prostora za unapređivanje online promovisanja samih hotela i turističke ponude lokalnih turističkih organizacija korišćenjem najznačajnijih manifestacija/događaja ima, dakle, u velikoj meri, a u skladu sa sve većom usmerenošću turista ka informisanju baziranom na Internetu i značaju koje manifestacije imaju u Moravičkom upravnom okrugu, zaključuje se da je razvoj ovakvog oblika promovisanja neophodan.

\section{Bibliografija}

1. Garabinovic, D., Papic, M., Analysis of attitudes about the use of information technologies and Internet marketing within different promotional strategies, In Nikitovic, Z., Markovic, D., D'Arconte, C. (ed.) Successful implementation of information technology: IT, marketing, education and business working together for business success, Silver \& Smith Publishers, London, pp. 51-82, 2018. Dostupno na: http://www.eeeconference.com/_img/arhiva/2018/knjiga_ii___it_marketing_prelom.pdf\#page=51. Strana: 67.

2. Nikitovic, Z., Garabinovic, D., Creating promotional strategies in accordance with consumer preferences, In Nikitovic, Z., Markovic, D., D’Arconte, C. (ed.) Successful implementation of information technology: IT, marketing, education and business working together for business success, Silver \& Smith Publishers, London, pp. 211-228, 2018. Strana: 222.

3. Kotler, P., Keller, K.L., Marketing menadžment, prevod dvanaestog izdanja, DATA STATUS, 2006. Strana: 536, 8.

4. Vlada Republike Srbije, Ministarstvo trgovine, turizma i telekomunikacija, Strategija razvoja turizma Republike Srbije 2016.-2025., novembar 2016. Strana: 28, 34.

5. Vićentijević, D., Status and prospects of tourism product development: Events/Festivals in Serbia, Hotel and Tourism Management, [S.I.], Vol. 3, No. 1, pp. 11-19, may 2018, ISSN 2620-0481 http://www.hit-vb.kg.ac.rs/htmanagement/index.php/HITM/article/view/68 (pristupljeno 17.12.2018, 21:10). Strana: 18.

6. Turistička organizacija Srbije, ProPozitiv, Stavovi i navike domaćih turista u Srbiji 2015 http://www.srbija.travel/upload/documents/ProPozitiv\%20i\%20TOS\%20prezentacija\%20i strazivanja\%20FINAL.pdf (pristupljeno 04.12.2018. 18:15). 
7. Bešić, C., Bogetić, S., Ćoćkalo, D., Uloga informaciono komunikacionih tehnologija u unapređenju procesa upravljanja marketingom u hotelskim preduzećima, Poslovna ekonomija, godina XII, broj 1, vol XXII, str. 140-161, 2018, doi: 10.5937/poseko1314862. Strana: 155.

8. Mašić, S., Kosar, N., Hotels and social media - case study of Serbia, In Thematic Proceedings I Tourism in function of development of the Republic of Serbia, The First Internation Scientific Conference, pp. 277-295, 2016, http://www.hitvb.kg.ac.rs/conference/images/thematic_proceedings/thematic-proceedings-i.pdf, (pristupljeno 17.12.2018., 21:16). Strana: 285, 287, 288.

9. Yang, Y. Pan, B., Song, H., Predicting hotel demand using destination marketing organizations' Web traffic data, Journal of Travel Research, Vol. 53, No. 4, pp. 433-447, 2014, https://doi.org/10.1177/0047287513500391.

10. Republički zavod za statistiku, Uporedni pregled broja stanovnika 1948, 1953, 1961, 1971, 1981, 1991, 2002. i 2011. po naseljima, Popis stanovništva, domaćinstava i stanova 2011. u Republici Srbiji, Stanovništvo, Beograd, 2014, ISBN 978-86-6161-109-4, http://pod2.stat.gov.rs/ObjavljenePublikacije/Popis2011/Knjiga20.pdf. Strana: 25.

11. Garabinović, D., Online marketing promotion of local tourism organizations: the analysis of the situation in Moravica administrative district. Hotel and Tourism Management, [S.1.], v. 7, n. 1, p. 71 - 81, june 2019. ISSN 2620-0481, https://doi.org/10.5937/menhottur1901071G . Available at: <https://www.hitvb.kg.ac.rs/htmanagement/index.php/HITM/article/view/190>. Date accessed: 15 sep. 2019. doi: https://doi.org/10.5937/menhottur1901071G. Strana: 76

12. Turistička organizacija Čačka, http://turizamcacak.org.rs/turisticka-ponuda/manifestacije/ (09.09.2019., 08:00)

13. Turistička organizacija opštine Gornji Milanovac, http://www.togm.org.rs/index.php/staraditi/manifestacije (09.09.2019., 09:11)

14. Turistička organizacija opštine Lučani "Dragačevo", http://turizamdragacevo.org/category/manifestacije/ (09.09.2019., 08:58)

15. Turistička organizacija opštine Ivanjica, https://www.ivatourism.org/sr/turistickaponuda/sta-raditi/manifestacije.html (09.09.2019., 09:28)

16. Ministarstvo trgovine, turizma i telokomunikacija, Kategorisani objekti Srbija - drugi kvartal 2019. godina, datum postavljanja: 03.04.2019., https://mtt.gov.rs/download/Други\%20квартал.xls (09.09.2019.)

\section{Istorija rada:}

Rad primljen: 07.10.2019.

Prihvaćen: 25.11.2019. 